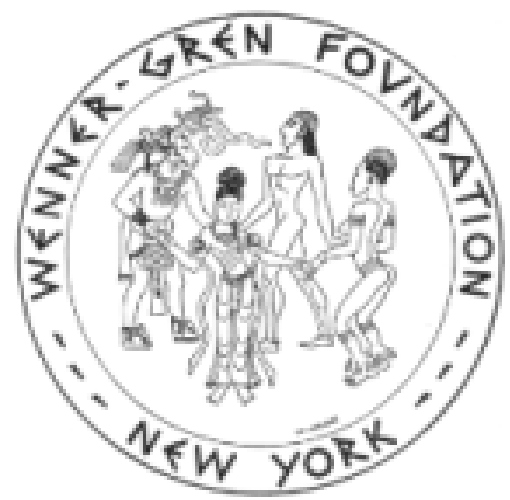

Phrenology and Physical Anthropology: The George Combe Connection Author(s): Paul A. Erickson

Source: Current Anthropology, Vol. 18, No. 1 (Mar., 1977), pp. 92-93

Published by: The University of Chicago Press on behalf of Wenner-Gren Foundation for Anthropological Research

Stable URL: http://www.jstor.org/stable/2741226

Accessed: 29/08/2013 12:14

Your use of the JSTOR archive indicates your acceptance of the Terms \& Conditions of Use, available at http://www.jstor.org/page/info/about/policies/terms.jsp

JSTOR is a not-for-profit service that helps scholars, researchers, and students discover, use, and build upon a wide range of content in a trusted digital archive. We use information technology and tools to increase productivity and facilitate new forms of scholarship. For more information about JSTOR, please contact support@jstor.org. 


\section{Phrenology and Physical Anthropology: The George Combe Connection ${ }^{1}$}

\author{
$b v$ Paul A. ERigkson \\ Department of Anthropology, Saint Mary's University, Halifax, \\ N. S., Canada B3H 3C3. 15 vi 76
}

Several histories of physical anthropology (Topinard 1885, Warren 1921, Riegel 1930, Hoyme 1953, Shapiro 1959, Comas 1960, Stanton 1960, Sheldon 1963, Harris 1968, Tether 1970, Davies 1971, Bowles 1974, Erickson 1974, Kottler 1974) mention a possible connection between 19th-century physical anthropology and phrenology. During the spring of 1975, I explored this possibility by examining, for their anthropological content, the papers of the influential Scots phrenologist George Combe (1788-1858). The papers are located in the National Library of Scotland, Edinburgh, and are a rich source of information comprising 351 volumes. Besides examining these papers I surveyed the anthropological content of the Phrenological Journal, organ of the Edinburgh Phrenological Society, and consulted Combe's publications and rare books about phrenology in the National Library. My goal was to delineate the similarities between early anthropology and phrenology and to discover what influence, if any, phrenology exerted on anthropology.

Beginning in 1859, European anthropologists formed professional societies, led by the Anthropological Society of Paris, the Anthropological Society of London, and the German Society for Anthropology, Ethnology, and Prehistory. Professional anthropologists debated questions about human evolution, the origin of races, the derivation of European ethnic groups, and the chronology of prehistory, all in the idiom of biology. Earlier, ethnologists had debated these and related questions in the idioms of history, geography, and philology, but anthropologists of the new societies, like Paul Broca in France, James Hunt in England, and Rudolph Virchow in Germany, made it clear that anthropology would be physical anthropology. They lacked a grand theoretical design to encompass these concerns, so they drew upon existing biological doctrines, some of them, like phrenology, on the biological periphery (Penniman 1936, Count 1950, Burrow 1963, Odom 1967, Haller 1971, Stocking 1973).

Phrenology preceded professional anthropology. It began about 1800 and became most popular when Combe and his friends promoted it during the 1820s and 1830s. From Edinburgh, at that time a leading scientific and intellectual center, the Combe circle published books, sponsored public lectures, and travelled abroad to make converts. Phrenology flourished until the $1830 \mathrm{~s}$, then declined because phrenologists began to bicker among themselves, became doctrinaire, and were discredited by flirting with mesmerism and animal magnetism. A second generation of phrenologists failed to develop, and because the movement had become a cult of individuals, it declined rapidly and really died with Combe in 1858 (de Giustino 1969). It left, however, a legacy to anthropology.

Combe's system was founded on the belief that the human mind acts through the human brain as its instrument. This belief was controversial in 1820 , but became more widely accepted and was an implicit assumption of anthropologists a half-century later. The belief that cerebral functions are localized in some 30 organs, for which phrenology is better known to historians, was a corollary of this more basic and enduring declaration. Combe considered phrenology to be a natural philosophy synthesizing anatomy and "metaphysics";

${ }^{1}$ A preliminary version of this research conclusion was presented to the History of Science Society meeting in Atlanta, Ga., December 29, 1975. A longer, documented version (Erickson 1976) is available from the author. I wish to thank the Canada Council for supporting my research with Research Grant S74-1345. anatomists alone, thought Combe, described cerebral structure without function, and metaphysicians (a tag for idealist and environmentalist philosophers) speculated about cerebral function without structure. With phrenology, knowledge of brain configuration would lead to knowledge of brain function and thereafter to knowledge of human behavioral capacities. Phrenology was a biological reductionist system, which, like 19th-century anthropology as contrasted with ethnology, belonged at the nature end of the nature-nurture spectrum (Combe 1819, 1824, 1935).

Combe tried to match personality with cerebral development as revealed in external skull shape, and he devised standard procedures and instruments for this purpose. Each cerebral organ was manifest in a corresponding faculty, and the organs and faculties were classed in an elaborate scheme. The techniques phrenologists used to measure cerebral development were like the techniques anthropologists used to measure skull size, shape, and, especially, capacity. The likeness can be seen by comparing the craniometric systems of Samuel George Morton and Combe, both of which appeared in Morton's Crania Americana (1839). Spreading calipers and an instrument called the craniometer, ancestor of the craniostat of today (Bowles 1974), were used to measure distances between phrenological landmarks corresponding to anthropological landmarks on the cranium. In theory, phrenology was supposed to be accurate and true to nature.

In practice, phrenology was inaccurate and easily falsifiable even by its own standards, but it was not irrelevant to anthropology. Believing that differences in skull shape were clues to differences in brain shape, mental function, and therefore behavior, Combe espoused a naturalistic moral philosophy wherein educational, social, and political institutions were supposed to respond to different innate capabilities of people. This hereditarian theme was echoed later by anthropologists, who were convinced that anthropology had practical applications too (Hunt 1863). Phrenologists and anthropologists alike thought of themselves as scientists, even though today it can be said that one group succeeded at science while the other failed. Both kinds of scientists tried to divorce their sciences from Old Testament theology, and both were accused by religious leaders of being materialistic. Although Combe was interested primarily in the skulls of Western people, he did analyze "national skulls" of non-Westerners and take a secondary interest in the facts of prehistory and in theories of the origin of races, of evolution, and of heredity-all anthropological concerns. The most obvious similarity between phrenologists and anthropologists was their common preoccupation with the human head. The history of early anthropology can be chronicled by major publications in the craniological tradition: Crania Americana and Crania Aegyptica (Morton 1839, 1844), Crania Britannica (Davis and Thurnam 1865), and Crania ethnica (Quatrefages and Hamy 1882). These and other similarities place phrenology squarely in the paradigm of 19th-century anthropology-contrasted with ethnology-defined by Stocking (1973).

There were, then, similarities between phrenology and early anthropology. There were also historical connections.

Phrenology had a large constituency including a significant number of medical people with anthropological interests. In 1836 there were more than 30 phrenological societies in Europe with a combined membership exceeding 900 people of the prosperous professional classes. The proportion of physicians and surgeons was about one of three in London and Edinburgh and about one of two in Paris (Watson 1836, List of Members 1831-32). In North America there were almost as many societies, and the proportion of medical people in the prominent Boston Phrenological Society was about one of four. The profile of this phrenological minority fits the profile of the later anthropological majority, in spite of the hostility and indifference with which phrenology was greeted by established medical 
organizations. Besides avowed phrenologists, many people in the broader scientific community were interested in phrenology, especially in North America, where Combe was feted by the Bostonian and Philadelphian elite. The content of the Phrenological fournal, reflecting the editorial posture of Combe and his associates, was also anthropological. The first volume alone contained eight articles about human anatomical variation and seven detailed descriptions of crania of famous, pathological, and non-Western people (Erickson 1976).

Moreover, phrenologists fostered the collection of skulls and contributed to knowledge of cranial anatomy. The Edinburgh Phrenological Society solicited donations from travellers and military and medical personnel throughout the British Empire, and it kept its collection in a museum in Edinburgh. Besides the smaller collections of regional societies, there were large collections in London and Paris, which were said to rival the crania of anthropologist Johann Friedrich Blumenbach. During the heyday of phrenology, anthropologists began to stress cranial capacity as an informative measurement, and some techniques and instruments were inherited by anthropology from phrenology directly (Hoyme 1953).

Combe corresponded with and about important figures in early anthropology. Some anthropologists rejected phrenology outright, others thought the doctrine was flawed, still others accepted it publicly or privately. Much of the Combe correspondence concerns the relationship between phrenology and religion and the application of phrenology to everyday life, but some of it, especially among medical people, concerns anatomy and physiology. James Cowles Prichard refused to accept phrenology and in turn provoked a response from Andrew Combe, who devoted several articles in the Phrenological Fournal to refuting Prichard's arguments (A. Combe 183738). William Lawrence (1819) was more sympathetic than Prichard, and, later, Davis and Thurnam invited Combe to become an original subscriber to Crania Britannica in the belief that Combe's prestige would increase prospects of success of their book (National Library of Scotland 1852:70). Robert Chambers was a close friend and supporter of Combe, and at one time Combe was suspected of being the author of Chambers's Vestiges of the Natural History of Creation. Morton's commitment to phrenology appears to have been stronger, privately at least, than historian Stanton (1960) suggests, and outspoken American anthropologist Charles Caldwell, from whom Morton obtained much of the ethnographic background for Crania Americana, published on phrenology and physical anthropology and the importance of both to race relations. Other prominent names that appear in the Combe correspondence are Georges Cuvier, W. F. Edwards, James Hunt, Robert Latham, Richard Owen, and Adolphe Quetelet.

In sum, historical data show that early anthropology and phrenology were similar in important ways and that phrenology contributed method and theory to anthropology. One could call phrenology a forerunner of professional anthropology, although a misguided one.

\section{References Cited}

Bowles, Francis P. 1974. Measurement and instrumentation in physical anthropology. Yearbook of Physical Anthropology 18:17490.

Burrow, J. W. 1963. Evolution and anthropology in the 1860's: The Anthropological Society of London, 1863-71. Victorian Studies 7:137-54

Comas, Juan. 1960. Revised and enlarged edition. Manual of physical anthropology. Springfield: Thomas.
Combe, Andrew. 1837-38. Remarks on Dr. Prichard's third attack on phrenology in his "Treatise on Insanity." Phrenological Journal 11:345-58.

Combe, George. 1819. Essays on phrenology, or An inquiry into the principles and utility of the system of Drs. Gall and Spurzheim, and into the objections made against it. Edinburgh: Printed for Bell and Bradfute.

Marshall. Anderson Jun.

Count, EARL. Editor. 1950. This is race: An anthology selected from the international literature on the races of man. New York: Henry Schuman.

Davies, John D. 1971. Phrenology: Fad and science. Archon Books.

Davis, Joseph Barnard, and John Thurnam. 1865. Crania Britannica: Delineations and descriptions of the skulls of the aboriginal inhabitants of the British Islands, with notices of their other remains. 2 vols. London: Printed for the Subscribers.

de Giustino, David Armand. 1969. Phrenology in Britain 18151855: A study of George Combe and his circle. Unpublished Ph.D. dissertation, University of Wisconsin, Madison, Wis.

Erickson, Paul A. 1974. The origins of physical anthropology. Unpublished Ph.D. dissertation, University of Connecticut, Storrs, Conn.

-1976. Phrenology and physical anthropology: The George Combe connection. MS.

HAller, John. 1971. Outcasts from evolution: Scientific attitudes of racial inferiority 1859-1900. Urbana: University of Illinois Press.

HARris, Marvin. 1968. The rise of anthropological theory: $A$ history of theories of culture. New York: Crowell.

Hoyme, Lucile. 1953. Physical anthropology and its instruments: A historical study. Southwestern Fournal of Anthropology 9:408-30.

Hunt, JAmEs. 1863. Introductory address on the study of anthropology. Anthropological Review 1:1-20.

Kottler, Malcolm Jay. 1974. Alfred Russel Wallace, the origin of man, and spiritualism. Isis 65:145-92.

Lawrence, William. 1819. Lectures on physiology, zoology, and the natural history of man. London: Printed for J. Callow, Medical Bookseller.

List of Members of the Phrenological Society of Paris, as at 25th April 1831. 1831-32. Phrenological fournal 7:302-3.

Morton, Samuel George. 1839. Crania Americana, or, A comparative view of the skulls of varnous aboriginal nations of $\mathcal{N}$ orth and South America. Philadelphia: J. Dobson.

- 1844. Crania Aegyptica, or, Observations on Egvptian ethnology, derived from anatomy, history and the monuments. Philadelphia: John Penington.

National Library of Scotland. 1852. MS 7336. Letters to Combe $\mathrm{F}-\mathrm{K}$.

Odom, Herbert. 1967. Generalizations on race in nineteenthcentury physical anthropology. Isis 58:5-18.

Penniman, T. K. 1936. A hundred years of anthropology. New York: Macmillan.

Quatrefages, Armand de, and E. T. Hamy. 1882. Crania ethnica: Les crânes des races humaines. 2 vols. Paris: Baillière

Riegel, Robert E. 1930. Early phrenology in the United States. Medical Life 37:361-76.

Shapiro, HARRY L. 1959, The history and development of physical anthropology. American Anthropologist 61:371-79.

Sheldon, W. H. 1963. The varieties of human physique: An introduction to constitutional psychology. With the collaboration of S. S. Stevens and W. B. Tucker. New York: Hafner.

Stanton, William. 1960. The leopard's spots: Scientific attitudes toward race in America, 1815-1859. Chicago: University of Chicago Press.

Stocking, George, JR. 1973. "From chronology to ethnology: James Cowles Prichard and British anthropology 1800-1850,", in Researches into the physical history of man, by James Cowles Prichard. Edited by George Stocking, Jr., pp. ix-cx. Chicago: University of Chicago Press.

Tether, J. Edward. 1970. "Brain," in Encyclopedia Americana, International edition, vol. 4, pp. 419-32.

Topinard, Paul. 1885. Eléments d'anthropologie générale. Paris: Adrien Delahaye et Emile Lecrosnier.

Warren, J. Collins. 1921. The collection of the Boston Phrenological Society-A retrospect. Annals of Medical History 3(1):1-11.

Watson, Hewetт C. 1836. Statistics of phrenology: Being a sketch of the progress and present state of that science in the British Islands. London: Longman, Rees, Orme, Brown, Green, and Longman. 